\begin{tabular}{c} 
OSOBA I Wina \\
Filozofia Chrzé́cijańska $\bullet$ Tom 9, Poznań 2012 \\
Uniwersytet im. Adama Mickiewicza w Poznaniu $\bullet$ Wydziat Teologiczny \\
\hline
\end{tabular}

ANDRZEJ JASTRZĘBSKI

Uniwersytet im. Adama Mickiewicza w Poznaniu

Wydział Teologiczny

Zakład Filozofii Chrześcijańskiej

\title{
Charakterystyka związku między zdaniami opisowymi a zdaniami normatywnymi
}

Characteristics of the Relationship between Descriptive Sentences and Normative Statements

Problem filozoficzny, który będzie przedmiotem rozważań w prezentowanym tekście w wersji polemicznej, został wyartykułowany przez Davida Hume'a w postaci następującego adagium łacińskiego: ab esse ad obligare non valet illatio, które za sprawą George'a Moore'a przeszło do historii pod nazwą błędu naturalistycznego. Krótko mówiąc, Hume nie zgadzał się na wyprowadzanie norm etycznych z opisowych twierdzeń metafizyki.

Zarówno problem ten, jak i proponowane jego rozwiązania mają jednakże znacznie dłuższą historię. Najbardziej klasyczna argumentacja na rzecz możliwości powiązania istnienia z normatywnością odnosi się do pojęcia natury ludzkiej. Przykładem takiego podejścia są poglądy Tomasza z Akwinu, który rację uzasadniania powinności moralnych upatrywał $\mathrm{w}$ treściowej zawartości natury ludzkiej, będącej przyczyną pożądania dobra jako takiego. Ta ogólna inklinacja człowieka miała być z kolei podstawą do podążenia za jakimkolwiek dobrem partykularnym. Należy przy tym dodać, że w ujęciu klasycznym naturę rozumiano w perspektywie metafizycznej, a nie faktycznej, jak to ma na przykład miejsce we współczesnej psychologii.

W czasach nowożytnych w swoim dziele $O$ wadach $i$ zaletach Hume zakwestionował wcześniejsze ujęcia klasyczne i zanegował możliwość wyprowadzenia norm etycznych $z$ treści natury ludzkiej. Twierdził, że moc powinności nie wypływa z obiektywnego prawa moralnego odczytywanego z natury, lecz z przeżywanych subiektywnie przez człowieka emocji. 
Poglądy Hume'a krytykował następnie Immanuel Kant, sam jednak nie znajdował metafizycznej podstawy do treściowych sformułowań praw moralnych. Jedyną podstawą etyki mógł być, zdaniem Kanta, wyłącznie rozum praktyczny, tj. wola niezależna od teorii. Postawę tego myśliciela Max Scheler nazywał później formalistycznym podejściem do etyki, a sam zaproponował materialną etykę wartości. Także u Kanta można jednak dopatrzeć się sformułowań ciążących ku etyce materialnej w poszczególnych sformułowaniach jego imperatywu kategorycznego - jest to jednak temat na inne opracowanie. Współcześnie do poglądów Kanta nawiązuje m.in. Christine Krosgaard.

Zadaniem, jakie sobie stawiamy w tym opracowaniu, nie jest definitywne rozwiązanie problemu powiązania zdań opisowych ze zdaniami normatywnymi. Cel poniższego tekstu jest o wiele skromniejszy. Chodzi przede wszystkim o ukazanie złożoności oraz doniosłości tego problemu, który jest podejmowany współcześnie już nie tylko w filozofii, ale także w naukach szczegółowych, gdzie też próbuje się przedstawiać propozycje jego rozwiązania. Okazuje się, że problematyka uzasadniania norm etycznych jest bardzo nośna, a możliwe odpowiedzi stają się jednocześnie wyznacznikami życia społecznego człowieka w zakresie ekonomii, polityki, prawa i innych dziedzin. Nie można więc pozwolić na to, aby brak ścisłej odpowiedzi filozoficznej na pytanie o charakter związku faktyczności z powinnością prowadził do dowolnego manipulowania teoriami etycznymi w świetle wyników badawczych uzyskiwanych na drodze indukcyjnej (nieniezawodnej). Dzieje się tak obecnie na polu psychologii oraz neurobiologii. $\mathrm{Na}$ ten właśnie fakt chcemy zwrócić uwagę $\mathrm{w}$ tym opracowaniu.

Wywód rozpocznie się od podania kilku uściśleń terminologicznych, następnie dokonamy krótkiej charakterystyki ujęć formalnych analizowanego zagadnienia. Ta część będzie miała charakter krótkiej syntezy dotychczasowych prób rozwiązywania interesującego nas problemu i ma służyć jako wprowadzenie do przeglądu przykładowych stanowisk filozoficznych oraz wybranych ujęć psychologicznych oraz neurobiologicznych.

\section{UWAGI WSTĘPNE}

Na początku wypada dookreślić, co rozumiemy przez zdania opisowe oraz zadania normatywne. Zdanie opisowe, inaczej teoretyczne, to takie, w którym zawiera się stwierdzenie faktu, opis rzeczywistości. Najczęściej składa się ono z podmiotu i orzecznika. Na przykład: „Jan jest wysoki” lub „Warszawa jest stolicą Polski”. Zdaniom takim w logice formalnej przypisuje się wartość 
prawdy albo fałszu w zależności od tego, czy zdanie teoretyczne pozostaje (albo nie) w zgodzie z rzeczywistością, którą opisuje. Z kolei zdanie normatywne (praktyczne, powinnościowe) rozumiemy przede wszystkim jako normę (regułę, przepis). Ma ono zawsze odniesienie do czegoś, co nie jest obojętne dla działającego podmiotu oraz jego postawy. Wśród tego typu zdań możemy rozróżnić przynajmniej rozkaźnikowe, normatywne i wartościujące ${ }^{1}$.

Podnoszony przez Moore'a problem błędu naturalistycznego dotyczy istnienia związku pomiędzy zdaniami teoretycznymi, wyrażonymi partykułą ,jest”, a zdaniami praktycznymi, wyrażonymi przez „powinien”. Konsekwencją takiego problemu jest także pytanie, czy zdaniom normatywnym przysługuje w ogóle wartość logiczna. Są to zagadnienia, które przenoszą nas na płaszczyznę rozważań metaetycznych. Wyzwanie rzucone przez Hume'a polega na tym, aby za pomocą dedukcji wyprowadzić zdania normatywne ze zdań opisowych. Do tej pory filozofom nie udało się w sposób jednoznaczny tego uczynić. Mniej ambitnym zadaniem w tym względzie jest próba określenia natury związku zdań opisowych ze zdaniami normatywnymi.

\section{REDUKCJA FILOZOFICZNA}

Jedną z możliwych strategii $\mathrm{w}$ wiązaniu zdań opisowych ze zdaniami normatywnymi jest zastosowanie redukcji filozoficznej. Przy dokładniejszej analizie związku zdań opisowych i normatywnych odkrywamy, że koniecznym warunkiem ,powinien” jest istnienie wolności działającego. Warunek ten można ująć w sformułowaniu: ,jest wolny”. Gdy zanegujemy ,jest wolny”, nie możemy powiedzieć ,,powinien”. Taki wniosek wyciagamy na podstawie doświadczenia oraz zasady niesprzeczności, przy czym kierunek implikacji postępuje od ,powinien” do ,jest”.

Z kolei kiedy twierdzenie antropologiczne umieścimy przed twierdzeniem etycznym, to twierdzenie antropologiczne (zdanie opisowe) staje się w pewnym sensie racją tezy etycznej przynajmniej na poziomie doświadczenia. Trudność opisania związku zdań opisowych ze zdaniami normatywnymi na drodze wyłącznie formalnej polega na wyraźnym odniesieniu się do treści twierdzenia powiązanego $\mathrm{z}$ doświadczeniem.

Kant twierdził, że „powinienem” zakłada „mogę, co jest logicznie równoważne z „nie mogę”, a więc „nie jestem zobowiązany”. Podczas gdy Hume

${ }^{1}$ S. Kamiński, Zdania praktyczne a zdania teoretyczne, „Roczniki Filozoficzne” nr 18 (1970), z. 1 , s. 81 . 
twierdził, że z ,jest” nie ma przejścia do „powinien”, Kant położył akcent na realne możliwości wypełnienia obowiązku moralnego. Jest to odniesienie $\mathrm{z}$ jednej strony do racjonalności zachowania człowieka, a z drugiej do jego dostępności oraz możliwości. Takie podejście relatywizuje jednakże „powinien" do dwóch wymiarów: racjonalności oraz potencjalności. Na przykład to, co jest racjonalne dla dorosłego, nie musi być takie dla dziecka. Można w tym kontekście wskazywać także na różnice kulturowe oraz środowiskowe 2 .

Racjonalność praktyczna może doprowadzić do wniosku, że należy kierować się takimi zasadami, których nie podważyłby nikt rozsądny ani obecnie, ani w wyobrażonej przyszłości. Według Christine Korsgaard, która rozwija myśl Kantowską, imperatyw kategoryczny integruje moralność człowieka poprzez „stosowaną” (applied) racjonalność każdego podmiotu. Bycie człowiekiem jest dla tej autorki praktyczną czy raczej normatywną formą tożsamości, do której należy odnieść odpowiednie wymagania praktyczne. Ponieważ każdy z nas jest podporządkowany własnej tożsamości, to jest to słuszne także w przypadku wymiaru normatywnego. Krótko mówiąc, nasza ludzka tożsamość daje nam wystarczające uzasadnienie, aby działać w ten, a nie inny sposób $^{3}$. Trzeba jednakże dodać, że taka praktyczna (i kontyngentna) tożsamość jest umocowana w swej ontologicznej bazie, którą klasycznie zwykło się określać jako naturę ludzką.

Krosgaard, idąc za Arystotelesem, określa człowieka jako zwierzę zdolne do refleksji, które potrzebuje motywacji do tego, aby działać i żyćc ${ }^{4}$ Z ludzkiej tożsamości wypływa rozumienie tego, co jest dobre, czyli odniesione do osoby. Bycie człowiekiem ujęte jako subiektywne doświadczenie normatywne (w odróżnieniu od doświadczenia czysto psychologicznego) stanowi bazę dla rozumienia tego, co czynić powinien. Jednocześnie poprzez wykonywanie słusznych działań człowiek sam się kształtuje.

Jeśli chcielibyśmy jednak sięgnąć do modelu implikacyjnego, możemy opisywać związek zdań typu ,jest” ze zdaniami typu „,powinien” w formie redukcyjnej, opartej na formule $q, p \rightarrow q$, więc $p$. Treściowa analiza twierdzenia normatywnego $q$ wskazuje na jego związek z pewnym twierdzeniem orzekającym $p$ i zarazem zakłada przyjęcie tego $p$ jako prawdziwego. Wykazanie związku $q$ z $p$ odbywa się przez zaprzeczenie $p$. Zaprzeczenie to $(\sim p)$ prowadzi do doświadczalnej sprzeczności $(\sim q)$. Przyjęcie $p$ jest więc konieczne, je-

${ }^{2}$ H.I. Brown, Psychology, Naturalized Epistemology, and Rationality, w: The Philosophy of Psychology, eds. W. O’Donohue, R.F. Kitchener, London - Thousand Oaks - New Delhi 1996, s. 20.

${ }^{3}$ C. Krosgaard, The Sources of Normativity, Cambridge 1996, s. 121-123.

${ }^{4}$ Tamże. 
śli chcemy także ,zachować” $q$. Mamy zatem implikację $\sim p \rightarrow \sim q$ ( $q$ uznajemy na podstawie doświadczenia). Zasada niesprzeczności zabrania nam przyjęcia zarazem $q \mathrm{i} \sim q$. Jeśli wybieramy $q$, pociąga to za sobą także $p$. Związek ten można przedstawić $\mathrm{w}$ postaci koniunkcji $\sim(q \rightarrow \sim p)$ lub w postaci implikacji $q \rightarrow p-$ nie możemy jednak twierdzić prawomocnie $p \rightarrow q^{5}$.

Kiedy (zatem) uznajemy powinność spełnienia jakiegoś czynu, zakładamy zarazem możliwość jego spełnienia. Nie możemy jednak wnioskować odwrotnie. Zdanie: „Powinieneś szanować swych pacjentów” nie może obowiązywać, jeśli osoba, do której norma jest kierowana, nie wykonuje zawodu związanego z szeroko pojętą opieką medyczną. Upraszczając: nie możesz (nie jesteś w stanie), a więc nie powinieneś (nie jesteś zobligowany).

\section{LOGIKA DEONTYCZNA}

Przedstawiony powyżej model wnioskowania typu redukcji filozoficznej nie ma charakteru dedukcyjnego, czyli niezawodnego. Trudność nastręcza przejście od „powinien $p$ " do samego $p$ lub odwrotnie od $p$ do ,powinien $p$ ”. Próba powiązania tez metafizycznych z tezami etycznymi na drodze redukcji pozostaje ostatecznie poza wnioskowaniami opisywanymi w logice przyjętej w wąskim sensie i podpada pod błąd natura li s ty c zn y Moore’a. Poza tym podnoszony jest też zarzut, że w opisywanej wyżej redukcji w sposób ukryty w tezach antropologicznych zawarte są już tezy normatywne ${ }^{6}$.

Czy można jednak udoskonalić - jak się wydaje - słuszną intuicję przejścia od „powinien” do „może”? Jeśli przyjmiemy, że zdania: ,jest możliwe, że $p$ ” i „nie jest możliwe, że $p$ ”; są zdaniami opisowymi (teoretycznymi) oraz oznaczymy ,powinien” przez „O”, a „może” przez „M”, to otrzymamy następujący zapis: Op $\rightarrow \mathrm{Mp}$, który w klasycznym rachunku zdań jest równoznaczny z: $\sim \mathrm{Mp} \rightarrow \sim \mathrm{Op}$. Dedukcja w tym miejscu wydaje się poprawna, jednak bliższa jej analiza ukazuje ponownie, że w zdaniach opisowych odwołujemy się do stanu rzeczy, a więc wprowadzamy do wnioskowania sformułowania treściowe, odchodząc przy tym od związków czysto formalnych, a stąd także od niezawodności dedukcji. Aby uniknać takiego problemu na gruncie logiki deontycznej, proponuje się następujące ujęcie zapisu: $\mathrm{O}(\mathrm{Op} \rightarrow \mathrm{Mp})$, który odczytujemy: „powinno być, że jeśli powinno być $p$, to jest możliwe $p$ )”.

\footnotetext{
${ }^{5}$ A. Buczek, Zwiazek między zdaniami teoretycznymi a praktycznymi, „Roczniki Filozoficzne" nr 23 (1975), z. 1, s. 34-35.

${ }^{6}$ Tamże, s. 37.
} 
Ostatecznie byłby do przyjęcia zapis $\mathrm{O}(\sim \mathrm{Mp} \rightarrow \sim \mathrm{Op})$, który czytamy: ,jeśli nie jest możliwe $p$, to nie jest obowiązkowe $p$ "7.

Propozycję rozwiązania problemu związku zdań opisowych ze zdaniami normatywnymi podaje także Roderick Chisholm ${ }^{8}$. Jeśli chcemy wyprowadzać „powinien” z ,jest”, musimy - zdaniem Chisholma - wziąć pod uwagę całą bogatą i złożoną rzeczywistość. Jego wnioskowanie można zilustrować na następującym przykładzie: Umówienie się na kawę z przyjacielem $(p)$ wymaga spotkania z przyjacielem $(q)$, lecz wypadek na drodze $(r)$ stwarza szersza sytuację ( $p$ oraz $r$ ), w której nie dochodzi do spotkania $(q)$. W ten sposób Chisholm odnosi się explicite do stanów rzeczy w orzekaniu powinności, zapewniając jednocześnie, że zawsze któryś stan rzeczy przeważy i pozwoli podjąć decyzję (dogmatyzm) - nie ukonkretnia jednak jaką - i to stanowi niewątpliwie słabość jego teorii.

\section{LOGIKA EPISTEMICZNA}

Przenieśmy się teraz na grunt logiki epistemicznej, która bada myślenie ludzkie jako takie. W logice tej występuje teza: ,jeśli $x$ wie, że $p$, to $p$ ", która zapiszemy w następujący sposób: $x W p \rightarrow p$. Wprowadzając do takiej tezy powinność $(O)$, mamy: $x W O p \rightarrow p$. Zbadajmy poprawność tej formuły, która staje się szczególnym przypadkiem tezy $x W p \rightarrow p$.

Po pierwsze, możemy przyjąć, że zasada $x W O p \rightarrow p$ jest zasadą ogólna. Po drugie, $O p$ ma charakter normatywny. Po trzecie, trzeba nam udowodnić, że $x W O p$ jest zdaniem opisowym. Trudnością jest tu występowanie elementu normatywnego $O p$. Nie każde jednak zdanie zawierające element normatywny staje się przez ten sam fakt zdaniem normatywnym. Czy $x W O p$ jest zatem zdaniem mieszanym?

Jeśli na gruncie ujęć formalnych nie udowodnimy, że analizowane zdanie jest zdaniem teoretycznym (opisowym), to nie wyjdziemy z błędnego koła złudzenia naturalistycznego. Widać stąd jasno, że jeśli filozofowie nie będą potrafili sformułować wyraźnych kryteriów, które pozwoliłyby (nam) odróżnić zdania normatywne od zdań mieszanych i czysto opisowych, nie będziemy mogli w sposób satysfakcjonujący rozwiązać problemu przejścia od ,jest”

\footnotetext{
${ }^{7}$ Tamże, s. 38.

${ }^{8}$ R.M. Chisholm, Ethics and Intrinsic Values, Heidelberg 2001.

${ }^{9}$ Por. P. Kawalec, Metaetyka czy prolegomena do teodycei?, „Ethos” nr 57-58 (2002), s. 362.
} 
do „powinien”. Wyzwanie stanowi wciąż analiza faktyczności normatywnego ,powinien” oraz ukrytej normatywności orzekającego ,jest"10.

\section{PODEJŚCIE FILOZOFICZNE}

Odmawianie wartości logicznej zdaniom praktycznym wiąże się z filozoficznym stanowiskiem odmawiającym realności relacji jako takiej. Ostatecznie, gdy na gruncie filozofii klasycznej przyjmujemy realnie istniejące relacje, możemy z metafizycznego poznania natury człowieka i jego relacji do celu przedmiotowego działania dojść do uzasadnienia zdań praktycznych. Trzeba przy tym jednak założyć określoną metafizykę i epistemologię. Widać stąd jasno, że jeśli nie jesteśmy w stanie powiązać zdań opisowych ze zdaniami normatywnymi za pomocą narzędzi logicznych, to odpowiedź na zarysowany problem zależy w dużym stopniu od perspektywy, z jakiej jest on rozwiązywany. Przedstawmy kilka przykładów tej zasady.

Na przykład utylitaryści twierdzą, że każde działanie człowieka jest moralnie obojętne i jest tylko pewnym aktem poznawczym. Ocena moralna jako punkt odniesienia przyjmuje społeczność, a konkretnie jak największe szczęście jak największej liczby ludzi. Na takiej bazie powstaje etyka konsekwencjonalna, co stanowi rozwinięcie stanowiska Hume'a.

Z kolei Stephen Finlay uważa, że należy rozwijać naturalistyczną teorię normatywności opartą na redukcyjnej semantyce ,powinien”. Wyróżnia przy tym takie funkcje ,powinien”, jak: predyktywna, instrumentalna oraz kategoryczna. Podstawowa jest pierwsza z nich, która charakteryzuje się różnym stopniem prawdopodobieństwa; $w$ funkcji instrumentalnej dochodzi modyfikacja ze względu na cel; natomiast kategoryczne „powinien” jest wyróżnionym zastosowaniem retorycznym wersji instrumentalnej, stającym się często moralnym „powinien”"11.

Podejście to stanowi przykład wyprowadzania zdań normatywnych z analiz języka oraz jego różnych funkcji. Jest o tyle niebezpieczne, że pomija się tu w ogóle odniesienie do rzeczywistości oraz obiektywną możliwość weryfikacji prawdziwości proponowanych tez.

Na szczęście nie brakuje filozofów, którzy na nowo podejmują klasyczne ujęcie analizowanego zagadnienia. Na przykład Robert Matava utrzymuje, że

${ }^{10}$ A. Buczek, Zwiqzek między zdaniami teoretycznymi a praktycznymi, „Roczniki Filozoficzne" nr 23 (1975), z. 1, s. 40-41.

${ }^{11}$ S. Finlay, Oughts and ends, „Philosophical Studies” Vol. 143 (2009), Issue 3, s. 315-340. 
odróżnienie ,jest” od „powinien” nie powinno być odnoszone do dychotomii pomiędzy porządkiem natury oraz porządkiem moralności ani pomiędzy wiedzą teoretyczną oraz wiedzą praktyczną. Zasady porządku moralnego znajduja, jego zdaniem, odzwierciedlenie w prawie naturalnym na tyle, na ile natura wyznacza warunki spełnienia się człowieka jako osoby. Dzięki osobistemu doświadczeniu własnej natury człowiek odkrywa w sposób niekonceptualny praktyczne zasady, które sprzyjają jego samospełnieniu. Jest to niespekulatywny rodzaj poznania, którego treść może stać się następnie przedmiotem adekwatnej refleksji filozoficznej ${ }^{12}$.

Również Athur Dyck broni klasycznego podejścia do zagadnienia relacji zdań opisowych i normatywnych. Twierdzi, że powinność może być odniesiona do wartości jako cechy przynależnej rzeczywistości, dzięki którym możemy ocenić adekwatność naszych sądów moralnych. Autor ten krytykuje współczesne podejścia redukcjonistyczne w odniesieniu do analizowanego problemu. Dla poparcia swoich tez zwraca się do psychologii Gestalt, w której można odnaleźć fenomenologiczny opis powinności oraz wartości jako doświadczenia rozbieżności pomiędzy tym, co człowiek czyni, a stawianymi mu wymaganiami. Doświadczenie moralnej „wymagalności” (requiredness) w istotny sposób różni się od doświadczeń wymagań logicznych, estetycznych i innych ${ }^{13}$. Dyskutując z ujęciami naturalizującymi, Dyck twierdzi, że wymagania moralne moga być postrzegane i uzasadniane z perspektywy idealnego obserwatora. W tradycji chrześcijańskiej jest nim Bóg. Zdaniem Dycka, jest to w pełni wiarygodna perspektywa dla formułowania norm etycznych ${ }^{14}$.

\section{PODEJŚCIE PSYCHOLOGICZNE}

Zmieńmy teraz nieco perspektywę i zobaczmy, w jaki sposób interesujący nas problem wszedł również do refleksji psychologicznej. Jako pierwszy przykład posłuży nam jeden z najbardziej kontrowersyjnych psychologów, reprezentant behawioryzmu, Burrhus Skinner.

W psychologii praktycznej Skinner chciał powiązać ,jest” nauk przyrodniczych (zdania opisowe) z ,powinien” etyki (zdania normatywne), odnosząc

${ }^{12}$ R.J. Matava, 'Is', 'Ought' and Moral Realism: The Roles of Nature and Experience in Practical Understanding, „Studies in Christian Ethics” Vol. 24 (2011), Issue 3, s. 311-328.

${ }^{13}$ A.J. Dyck, Moral requiredness: bridging the gap between „ought” and „, is”, ,Journal of Religious Ethics" Vol. 6 (1978), s. 293-318.

${ }^{14}$ Idem, Moral requiredness: bridging the gap between „ought” and „is”, ,Journal of Religious Ethics" Vol. 9 (1981), no 1, s. 131-150. 
się w tym celu do prawidłowości statystycznych występujących wśród ludzi a stanowiących przedmiot badań psychologii. Karl Popper zarzucał tej próbie, że wobec faktów socjologicznych mówiących o tym, że większość ludzi przyjmuje zasadę „Nie kradnij”, można albo przyjąć tę zasadę jako normę, albo nie. Poza tym istnieje także możliwość zniechęcania albo zachęcania tych, którzy przyjęli tę zasadę, do jej przestrzegania albo nawet do przyjęcia innej zasady. Nie jest w tym sensie możliwe wyprowadzenie zdania określającego normę lub decyzję ze zdania opisującego fakt, czyli wyprowadzanie norm $\mathrm{z}$ faktów ${ }^{15}$.

Wedle Skinnera wniosek Poppera jest poprawny tylko wówczas, gdy istnieje możliwość wyboru pomiędzy normami. Jeśli człowiek jest zdeterminowany zewnętrznymi warunkami, to nie ma wolności wyboru. Skoro rozumowanie Poppera takową wolność zakłada, to jego argument ma, zdaniem Skinnera, bardzo ograniczoną wartość ${ }^{16}$.

Według Skinnera moralnie dobre jest to, co daje wzmocnienie odpowiedniego zachowania. Według zwolenników teorii błędu naturalistycznego Moore'a nie można wyprowadzać zdań normatywnych, stanowiących o tym, co jest dobre, na podstawie danych czysto faktualnych. Jeśli podążymy za rozumowaniem Skinnera, gdzie dobre jest to, co daje wzmocnienie, to nie będziemy pytać o to, czy coś jest dobre, lecz o to, czy daje wzmocnienie. Jednakże możemy zasadnie pytać, czy każde wzmocnienie jest dobre.

Podajmy też przykład bardziej współczesny, a wywodzący się z psychologii poznawczej (kognitywnej), skupiającej swoją uwagę na zasadach kierujących myśleniem człowieka. Wśród reprezentantów tego kierunku psychologicznego istnieją obecnie głosy (np. Shira Elqayam i Jonathan Evans), które podważają normatywny wymiar myślenia ludzkiego. Według tego ujęcia normatywizm w myśleniu zawsze prowadzi do wikłania się w nierozwiązywalną aporię ,jest-powinien”. Dowody empiryczne mogą nam pomóc jedynie w rozwiązywaniu kwestii opisowych, ale już nie normatywnych. Należy zatem rozróżnić normatywizm od kompetencji praktycznych oraz zająć się raczej opisową stroną tychże kompetencji w kluczu analizy komputacyjnej. Tego rodzaju deskryptywizm w zakresie procesów mentalnych według omawianych psychologów miałby być alternatywą dla rozważań typu czysto normatywnego ${ }^{17}$.

${ }^{15}$ R. Garrett, Skinner's Case for Radical Behaviorism, w: The Philosophy of Psychology, s. 145.

${ }^{16}$ Tamże, s. 146.

${ }^{17}$ S. Elqayam, J.S. Evans, Subtracting „ought” from „is”: Descriptivism versus normativism in the study of human thinking, „Behavioral \& Brain Sciences” Vol. 34 (2011), Issue 5, s. 233-248. 
Mike Oaksford oraz Nick Chater dyskutują z podejściem Elqayam i Evansa, twierdząc, że zwykły opis tego, jaki świat jest, nie może od razu determinować, jak powinniśmy o nim myśleć oraz jak mamy postępować. Rozważania normatywne nie muszą zaraz podkopywać możliwości adekwatnej analizy rozumowań człowieka. Analiza racjonalności człowieka nie polega na tym, żeby wskazywać na to, jak ludzie powinni myśleć, lecz w jaki sposób faktycznie myślą. Refleksja normatywna nie może być wobec tego sprowadzona tylko do analizy racjonalności człowieka ${ }^{18}$.

\section{PODEJŚCIE NEURONAUKOWE}

Współcześnie istnieją też próby zastąpienia tradycyjnego podejścia normatywnego nienormatywną deskryptywno-kauzalną nauką kognitywną, którą można także określić mianem nienormatywnego naturalizmu. Na przykład Patrycja Churchland uważa, że można wyprowadzać „powinno być” z ,jest”. Choć nie można $\mathrm{w}$ tym miejscu mówić wprost o dedukcji, to można mówić o prawdziwości. Z perspektywy neuronaukowej proces decyzyjny u człowieka nie jest owocem zestawienia ciągu zdań normatywnych (rozumowania praktycznego), ale raczej praktyki życiowej oraz historii rozwoju ośrodkowego układu nerwowego konkretnej jednostki. W sposób oczywisty podejście to promuje redukcjonizm biologiczny w budowaniu etyki. Wnioski tą droga wyciągane można by streścić w następujący sposób: „Postępuję tak, a nie inaczej, ponieważ zmusza mnie do tego określona struktura oraz funkcjonowanie mojego układu nerwowego"19.

Najważniejszym zarzutem wobec takiego podejścia do wiązania zdań opisowych ze zdaniami normatywnymi mimo jego deklarowanej neutralności jest powrót do błędu naturalistycznego przez to, że z faktów dotyczących formowania się oraz zmiany przekonań wyciagga się wnioski na temat tego, co powinno być uznane za słuszne. Odkrycia neuronaukowe dotyczące zjawisk umysłowych mają wartość wyłącznie opisową. Istotną częścią epistemologii i etyki jest z kolei ustanowienie określonej normatywności. Przyjmując powyższą strategię badawczą, narażamy się na mieszanie podejścia opisowego $\mathrm{z}$ podejściem normatywnym ${ }^{20}$. Ostatecznie nauki przyrodnicze nie mogą usta-

${ }^{18}$ M. Oaksford, N. Chater, The ,is-ought fallacy” fallacy, „Behavioral \& Brain Sciences” Vol. 34 (2011), Issue 5, s. 262-263.

${ }^{19}$ P.S. Churchland, Inference to the Best Decision, w: The Oxford Handbook of Philosophy and Neuroscience, ed. J. Bickle, Oxford 2009, s. 427.

${ }^{20}$ H. Siegel, Naturalism and the Abandonment of Naturalism, w: The Philosophy of Psychology, s. 6. 
nowić norm etycznych. Mogą co najwyżej dostarczyć pewnych narzędzi do oceny rzeczywistości oraz wskazania adekwatnych sposobów wypełniania norm moralnych ${ }^{21}$.

\section{ZAKOŃCZENIE}

Rozważania na temat możliwości powiązania zdań opisowych ze zdaniami normatywnymi ukazują niezwykłą złożoność, a jednocześnie wielką doniosłość tego zagadnienia. Jak dotychczas filozofowie nie wypracowali jednoznacznego ujęcia omawianego problemu, co oczywiście oddala nas od jego satysfakcjonującego rozwiązania. Co ciekawe z czasem do dyskusji włączyli się przedstawiciele innych nauk o człowieku: społecznych oraz przyrodniczych.

Okazuje się, że rozwiązania nieformalne (humanistyczne i przyrodnicze) są powiązane w dużym stopniu z przyjmowanym rozumieniem rzeczywistości czy światopoglądem. Promowanie różnego rodzaju redukcjonizmów w rozumieniu natury człowieka, a przez to także jego świata wartości i powinności, jest bardzo krótkowzroczne, ponieważ pomija całe bogactwo bytu ludzkiego, z którego w sposób integralny wypływa jego moralność. Należy więc zachować czujność i nie przyjmować pochopnie uproszczonych rozwiązań, jakich przykład mamy w poglądach Patrycji Churchland.

Powracając do ujęć formalnych, należałoby stwierdzić, że wnikliwsza analiza zdań dotyczących natury człowieka wykazuje, że są one zdaniami mieszanymi - zawierają w sobie odniesienie normatywne poprzez przydanie naturze cech normatywnych a priori lub przez wybór etycznych kryteriów jej opisu. Podważona jest tym samym prawomocność wnioskowania redukcyjnego. Człowiek musi wiedzieć, kim jest, aby spełnić powinność, ale jeśli w tym ,wiedzieć" zawiera się także element normatywny, to natrafiamy na znaną już nam trudność i problem przejścia od ,jest” do „powinien” traci znów swą doniosłość. Wobec powyższych trudności jasne sformułowanie kryteriów pozwalających na odróżnienie zdań teoretycznych od zdań praktycznych pozostaje wciąż zagadnieniem centralnym.

Być może postulat podania kryteriów pozwalających na odróżnienie zdań praktycznych od zdań teoretycznych jest w praktyce niemożliwy do realizacji, ponieważ tak zdania opisowe, jak i zdania normatywne są zdaniami mie-

${ }^{21}$ W.T. O'Donohue R. Mangold, A Critical Examination of The Ethical Principles of Psychologists and Code of Conduct, w: The Philosophy of Psychology, s. 377. 
szanymi, które zawierają w sobie i elementy opisowe, i wezwanie do jakiegoś określonego działania. Samo doświadczenie pokazuje też, że zdania teoretyczne i praktyczne spotykają się w rzeczywistości ze sobą i nawzajem na siebie wpływają. Możemy mówić o ich paralelizmie oraz wzajemnej odpowiedniości, która nie ma jednak charakteru wnioskowania logicznego i wobec tego pozostaje otwarta na bardziej dowolne analizy metafizyczne, psychologiczne i inne, z czym wiąże się niebezpieczeństwo, że stanie się „droga na skróty" dla adekwatnego rozumienia człowieka oraz jego powinności. Zagrożenie to powinno być nieustanną zachętą dla filozofów do podejmowania wymagającej skądinąd problematyki natury związku zdań opisowych ze zdaniami normatywnymi.

\section{SUMMARY}

The philosophical problem that is the focus of this article was polemically coined by David Hume and expressed in a Latin phrase: ab esse ad obligare non valet illatio. Thanks to George Moore, this statement entered into the history of philosophy as the naturalistic fallacy. Hume questioned the possibility of deriving ethics from natural law. He was convinced that moral obligation has its roots rather in human emotions. Subsequently both Immanuel Kant in his categorical imperative, and Max Scheler in his material ethics of values, disputed Hume's statement.

In the present article we will try to address the issue of the naturalistic fallacy, which denies the possibility of deriving an „ought” from an ,is”, first of all in the field of formal logic. Afterwards, we will analyze the relationship of descriptive and normative statements philosophically, psychologically and, in the end, neuroscientifically - all this in order to answer the question whether there is any possible link between those two types of statements.

\section{Keywords}

naturalistic fallacy, ,is” and „ought”, descriptive sentences, normative sentences 